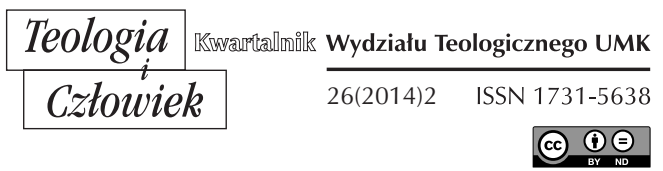

KS. TOMASZ DUTKIEWICZ*

\title{
EKOTERRORYZM A ROZTROPNA TROSKA O ŚRODOWISKO NATURALNE. METAFIZYCZNO-BIBLIJNE ASPEKTY ZAGADNIENIA
}

DOI: http://dx.doi.org/10.12775/TiCz.2014.018

\section{WSTĘP}

Zagadnienia związane $\mathrm{z}$ ochroną środowiska naturalnego należą z pewnością do stanowiących przedmiot częstych dyskusji oraz niosą ze sobą niemały ładunek emocjonalny. Warto w tym kontekście zauważyć, że - tak powszechne współcześnie - zainteresowanie problematyką ekologiczną pojawiło się stosunkowo niedawno. Przyczyna tego faktu wydaje się oczywista: przez całe stulecia to nie człowiek i jego działalność w świecie mogły być zagrożeniem dla świata przyrody, ale przeciwnie to przyroda stanowiła nieprzyjazne człowiekowi środowisko, z którym musiał się zmagać w trudnej walce o przetrwanie.

To przetrwanie, mimo słabego biologicznego przystosowania do otoczenia (brak naturalnego uposażenia w postaci sierści, kłów, pazurów itp.), człowiek zawdzięcza swoim zdolnościom intelektualnym, dzięki którym stał się twórcą narzędzi, czego wyrazem jest łacińskie określe-

* Ks. dr hab. Tomasz Dutkiewicz jest adiunktem w Zakładzie Teologii Fundamentalnej i Religiologii Wydziału Teologicznego Uniwersytetu Mikołaja Kopernika w Toruniu. 
nie homo faber bądź też bardziej współczesne: tool making animal. Fakt tworzenia narzędzi okazał się na tyle istotny, że poszczególne epoki w dziejach ludzkości zaczęto nazywać, odwołując się do ich specyfiki, mówiąc o epoce kamienia, brązu, żelaza, pary wodnej, elektryczności, energii nuklearnej itp. Jak nietrudno zauważyć, wraz z rozwojem nauki oraz - stanowiącym jego owoc - postępem technicznym narzędzia te stawały się coraz bardziej efektywne, przez co posługiwanie się nimi w coraz poważniejszym stopniu oddziaływać poczynało na zastane, naturalne środowisko życia człowieka.

Fakt ten uświadomił człowiekowi potrzebę zwrócenia uwagi na problematykę ochrony tego środowiska, zarówno w aspekcie techniczno-przyrodniczym, jak i etyczno-moralnym. Warto $\mathrm{w}$ tym kontekście zaznaczyć, że jednym z pierwszych głosów w tej dziedzinie był głos Kościoła. Na aspekt moralny postępującej degradacji środowiska naturalnego zwrócił uwagę papież Paweł VI, kierując 4 października 1965 roku swoje orędzie do Organizacji Narodów Zjednoczonych. Również Sobór Watykański II w konstytucji duszpasterskiej o Kościele w świecie współczesnym Gaudium et spes krytycznie odniósł się do postawy będącej wyrazem przekonania, że "rzeczy stworzone nie zależą od Boga, a człowiek może ich używać bez odnoszenia ich do Boga"1.

Obok głosów będących wyrazem uzasadnionej troski o środowisko naturalne obserwować można jednak cały szereg wypowiedzi skrajnych, w myśl których „człowiek jest rakiem Ziemi”, „barbarzyńcą", „agresywną małpą" itp. ${ }^{2}$ Niektóre organizacje o charakterze ekologicznym odwołują się do postulatów tak absurdalnych, jak np. zmniejszenie dla dobra Ziemi zamieszkującej ją ludzkiej populacji o ok. 90\% (postulat taki sformułował działający w Stanach Zjednoczonych ruch o nazwie Earth First - „Najpierw Ziemia”) ${ }^{3}$. Inne w celu wprowadzenia w życie swoich ideologii sięgają po środki, takie jak podpalenia, zamachy bombowe, specjalne przesyłki-pułapki z zarazkami śmiertelnych chorób, dostarczane właścicielom firm hodowlanych, przetwórni mięsnych, zakładów futrzarskich itp. Wielką Brytanią wstrząsnęła w połowie lat 90. fala zamachów skierowanych przeciwko hodowcom, zakładom przetwórstwa mięsnego

${ }^{1}$ Zob. S. Zięba, Teologiczny wymiar kryzysu ekologicznego, w: Ekologia. Przestanie moralne Kościoła, red. J. Nagórny, Lublin 2002, s. 21.

2 Tamże, s. 36.

${ }^{3}$ Zob. P. H. Kieniewicz, Ekologia - szansa czy zagrożenie, w: Ekologia. Przestanie moralne Kościoła, red. J. Nagórny, s. 53-54. 
i restauracjom. Podpalano ludzi noszących futra oraz detonowano ładunki wybuchowe w sklepach zajmujących się ich sprzedażą. Ocenia się, że Radykalny Front Wyzwolenia Zwierząt, w szczególności zaś jego mutacja pod nazwą "Milicja Wyzwolenia Zwierząt”, stał się, po terroryzmie IRA, najpoważniejszym zagrożeniem dla mieszkańców Zjednoczonego Królestwa ${ }^{4}$.

W świetle powyższych faktów w uzasadniony sposób mówić można o zjawisku tzw. ekoterroryzmu czy też nawet ekofaszyzmu. Ksiądz prof. Zwoliński, podejmując tę kwestię w pracy zatytułowanej Rozdroża ekologii, zwraca uwagę na fakt stopniowego przechodzenia od głoszonej ideologii do stosowania coraz bardziej radykalnych środków, mających służyć jej urzeczywistnieniu: początkowo w imię obrony "praw zwierząt” (animal rights) głoszono idee wegetarianizmu, urządzano pikiety firm hodujących zwierzęta na ubój, kontestowano handel wyrobami futrzarskimi; później jednak przyszedł czas akcji bezpośrednich, polegających na niszczeniu obiektów, uwalnianiu siłą zwierząt z farm hodowlanych, laboratoriów itp. Założyciel tzw. Animal Liberation Front (Front Wyzwolenia Zwierząt), Ronnie Lee, przestrzegał wprost: „Będą ranni i być może zabici po obu stronach [...] zanim odniesiemy ostateczne zwycięstwo w walce o wyzwolenie zwierząt. To smutne, ale nieuchronne"

Wydaje się, że przyczyny nieporozumień wokół kwestii związanych z ochroną środowiska naturalnego są złożone. Można się doszukiwać ich na gruncie rozpowszechnianych celowo, fałszywych informacji z dziedziny nauk przyrodniczych, stanowiących rodzaj karty przetargowej, służącej realizacji partykularnych interesów ekonomicznych, na co zwraca uwagę m.in. P. Masztalerz w swojej książce Ekologiczne kłamstwa ekowojowników. Rzecz o szkodliwości kłamliwej propagandy ekologicznej, wykazując absurdalność całego szeregu „naukowych” poglądów, funkcjonujących niemal powszechnie na poziomie tzw. opinii publicznej (warto podkreślić, że sam autor jest profesorem chemii, autorem kilkunastu monografii z dziedziny chemii organicznej oraz biochemii, a także pięciu podręczników akademickich) ${ }^{6}$.

${ }^{4}$ Zob. A. Zwoliński, Pozachrześcijańskie orientacje i ruchy ekologiczne w Polsce, w: T. Ślipko, A. Zwoliński, Rozdroża ekologii, Kraków 1999, s. 243.

5 Zob. tamże, s. 242.

${ }^{6}$ Zob. P. Masztalerz, Ekologiczne kłamstwa ekowojowników. Rzecz o szkodliwości kłamliwej propagandy ekologicznej, Wrocław 2000. 
W kontekście rozważań o charakterze filozoficznym i teologicznym na szczególniejszą uwagę zasługiwać będą jednak przyczyny błędnych ujęć problematyki środowiska naturalnego sięgające metafizyki, na które wskazuje m.in. ks. prof. A. Maryniarczyk w swojej książce Metafizyka w ekologii ; antropologii i etyki, co w swoich licznych opracowaniach przedstawia m.in. ks. prof. T. Ślipko; a także egzegezy Pisma Świętego, którego wyrywkowa i wybiórcza lektura stała się na terenie omawianej przez nas problematyki źródłem licznych nieporozumień.

Celem podjętej $w$ ramach artykułu refleksji będzie ukazanie fałszywych przesłanek filozoficznych i teologicznych, przyjmowanych przez zwolenników niektórych skrajnych inicjatyw ekologicznych, a także wskazanie - jak zostało to sformułowane $\mathrm{w}$ podtytule - metafizycznych oraz biblijnych podstaw właściwie pojętej troski o środowisko naturalne. Jako że zjawisko „ekoterroryzmu” w szczególny sposób wiąże się z działalnością organizacji występujących $w$ obronie zwierząt, w centrum naszego zainteresowania pozostanie relacja człowieka do świata zwierzęcego.

\section{BŁĘDNE UJĘCIA RELACJI CZłOWIEK-PRZYRODA}

Zarówno postawa agresywnej eksploatacji dóbr ziemskich, dokonującej się w imię dążenia do ciągłego wzrostu konsumpcji oraz do podnoszenia stopy życiowej z oczywistą szkodą dla środowiska naturalnego, jak i postawa wyrażająca skrajną tendencję do zachowania tego środowiska w stanie nienaruszonym i nieskażonym, ze szkodą dla żywotnych interesów ludzkiego gatunku, wyrastają z fałszywych ujęć relacji człowiek-przyroda ${ }^{8}$.

Przywołany już wcześniej ks. prof. Ślipko odwołuje się w tym kontekście do pojęcia paradygmatów, a więc pewnych modelowych sposobów interpretowania tej relacji. U podstaw tych ujęć-paradygmatów dostrzec można błędne założenia sięgające zarówno metafizyki, jak i teologii.

7 A. Maryniarczyk, Metafizyka w ekologii, Lublin 1999. Zagadnienie to wcześniej podjął także o. M. A. Krąpiec. Zob. tenże, "Idea postępu” w krzywym zwierciadle ekologii, "Człowiek w Kulturze" 2 (1994), s. 17-28.

${ }^{8}$ Jest rzeczą sygnalizowaną przez licznych autorów, że u podstaw nieuporządkowanych odniesień człowieka do świata przyrody leży tzw. błąd antropologiczny. W doniosły sposób na fakt ten zwrócił uwagę Jan Paweł II w encyklice Centesimus annus. Zob. tamże, 37. Zob. też: S. Nowosad, Antropologiczno-etyczny wymiar ekologii, w: Ekologia. Przestanie moralne Kościoła, red. J. Nagórny, s. 57 nn. 


\subsection{PARADYGMAT DOMINACJI CZŁOWIEKA NAD PRZYRODA}

Pierwszy ze wspomnianych paradygmatów nazwać można, jak czyni to ks. Ślipko, paradygmatem dominacji czy też „władztwa” człowieka nad przyrodą. Jego krytycy, rekrutujący się ze środowisk niechętnie bądź też wrogo nastawionych w stosunku do religii chrześcijańskiej, zwykli eksponować jego rzekome biblijne korzenie, obciążając tym samym zawarte w Księdze Rodzaju polecenie czynienia sobie przez człowieka ziemi poddaną, odpowiedzialnością za wszelkie nadużycia, jakich dopuścił się on $\mathrm{w}$ przeszłości i wciąż dopuszcza się $\mathrm{w}$ stosunku do świata przyrody.

Dlaczego zarzut ten uznać trzeba za niesłuszny, sam zaś paradygmat władztwa człowieka nad przyrodą za pozbawiony zarówno biblijnych, jak i metafizycznych podstaw?

Odpowiadając na pierwszą część postawionego pytania, zwrócić warto uwagę na dość charakterystyczny mechanizm powstawania błędnych nauk, zwanych tradycyjnie herezjami. To właśnie grecki czasownik „wybierać", od którego pochodzi termin hairesis - „herezja”, pozwala

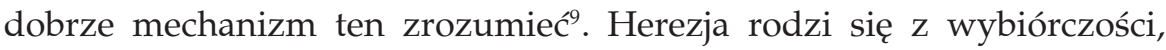
$\mathrm{z}$ wyeksponowania pewnego aspektu rzeczy, z pominięciem pozostałych (warto zauważyć, ze wszelkie ludzkie poznanie jest z konieczności aspektowe, tzn. nie ogarnia ono całości poznawanej rzeczy, ale rozbija ją na aspekty; np. w przypadku poznania zmysłowego jest rzeczą oczywistą, że widząc "przód” przedmiotu, nie widzimy jednocześnie jego „tyłu”; podobnie jest również $\mathrm{w}$ przypadku ujęć intelektualnych, w których przedmiot poznawany zostaje niejako „rozbity” na poszczególne aspekty, postrzegany z różnych perspektyw; w odniesieniu do lektury Pisma Świętego powiemy tutaj o wielości obrazów biblijnych, które dopiero razem wzięte, pozwalają właściwie odczytać prawdę objawioną $)^{10}$.

Mając na uwadze powyższą konstatację, trzeba podkreślić, że biblijny tekst, zawierający polecenie „czynienia sobie ziemi poddaną", choć jest być może najpowszechniej znanym fragmentem Pisma Świętego, odnoszącym się do relacji człowiek-świat stworzony, to z całą pewnością nie jest jednak tekstem jedynym.

${ }^{9}$ Herezja (gr. heiresis) to dosłownie: „branie dla siebie”, „wybór”. Zob. W. Kopaliński, Stownik wyrazów obcych i zwrotów obcojęzycznych, Warszawa 1968, s. 301.

${ }^{10}$ Odczytanie to - jak poucza Sobór Watykański II - musi się ponadto dokonywać w świetle Tradycji Kościoła, z uwzględnieniem analogii wiary. Zob. Dei verbum, 12. 
W Księdze Mądrości na przykład, znaleźć możemy dodatkową, niezmiernie istotną informację, pouczającą $\mathrm{w}$ jaki sposób panowanie człowieka nad światem ma być realizowane:
„Boże ojców i Panie miłosierdzia,
któryś wszystko uczynił swym słowem
i w mądrości swojej stworzyłeś człowieka,
by panował stworzeniom co przez Ciebie się stały,
by władał światem w świętości i sprawiedliwości
i w prawości serca sądy sprawował"11.

Panowanie człowieka nad światem przyrody, w myśl powyższego tekstu, ma się dokonywać „w świętości i sprawiedliwości”. Nie powinno ono zatem przybierać formy samowolnego używania i nadużywania dóbr naturalnych $\mathrm{z}$ pogwałceniem zapisanego w naturze ładu moralnego. Prawdę tę potwierdza również użyty w przywołanym wcześniej poleceniu "czynienia sobie ziemi poddaną" hebrajski czasownik radah, który ma znaczenie szersze aniżeli polskie słowo „panować", oznaczając również „bycie przewodnikiem, pasterzem"12.

Także teksty Pisma Świętego akcentujące fakt, że świat przyrody stanowi swoistą Księgę, w której objawił się Stwórca i z której ludzki intelekt zdolny jest odczytać prawdę nie tylko o Jego istnieniu, ale także o Jego „przymiotach i Bóstwie”, w sposób oczywisty wskazują jako jedyną właściwą postawę szacunku i podziwu wobec tego świata (w szczególności wymienić tutaj należy tekst z trzynastego rozdziału Księgi Mądrości oraz z pierwszego rozdziału Listu do Rzymian, na których Sobór Watykański I oparł ogłoszony na nim dogmat o naturalnej poznawalności Boga) $)^{13}$.

Reasumując, stwierdzić możemy, że stworzony przez Boga świat, taki jakim ukazuje go Objawienie nadprzyrodzone, nie jest światem bez-

${ }^{11}$ Mdr 9,1-3.

${ }_{12}$ Zob. T. Ślipko, Ekologiczna doktryna Kościoła, w: T. Ślipko, A. Zwoliński, Rozdroża ekologii, s. 67.

${ }^{13}$ W konstytucji soborowej Dei Filius o wierze katolickiej z 24.04.1870 czytamy: „święta Matka Kościół utrzymuje i naucza, że naturalnym światłem ludzkiego rozumu można z rzeczy stworzonych na pewno poznać Boga, początek i cel wszystkich rzeczy". Cyt. za: Breviarium fidei, red. I. Mokwa, Poznań 2007, nr 641. Świat stanowi zatem swoistą "księgę" objawienia, które dokonało się w stwórczym akcie Boga. Zagadnienie to podejmuje szerzej Jan Paweł II w encyklice Fides et ratio. Zob. tamże, nr 19; nr 22. 
pańskim, ale przeciwnie - jest „światem Pańskim”. Stwierdzenie to ma swój ogromny ciężar gatunkowy.

Do podobnych wniosków prowadzi także refleksja metafizyczna, na gruncie której sformułować możemy odpowiedź na drugą część postawionego wcześniej pytania: dlaczego paradygmat władztwa człowieka nad przyrodą pozbawiony jest rzetelnych metafizycznych podstaw. Refleksja ta bowiem, zmierzając do wyjaśnienia świata, danego człowiekowi w bezpośrednim poznaniu zmysłowym poprzez wskazanie na jego pierwszą i ostateczną przyczynę, prowadzi do odkrycia istnienia Bytu Absolutnego, będącego zarazem Stwórcą i celem wszelkich bytów stworzonych.

Również poprawne odczytanie natury człowieka, jego miejsca w świecie, nade wszystko zaś jego zależności w bytowaniu od Boga, jego ostatecznego ukierunkowania na Stwórcę jako na Najwyższe Dobro, do którego - świadomie bądź też nie - dąży on w swoich aktach, fakt że w swojej naturze odczytuje on prawo, którego sam sobie nie nadaje, ale które zastaje i którym winien się kierować, każą odrzucić jako pozbawiony metafizycznych podstaw (a raczej oparty na błędnych metafizycznych przesłankach) tzw. humanizm antropocentryczny, stanowiący fundament paradygmatu dominacji człowieka nad przyrodą ${ }^{14}$.

\subsection{PARADYGMAT PARTNERSTWA}

Drugi z paradygmatów w zamyśle wielu spośród odwołujących się do niego autorów ma stanowić remedium na nadużycia, będące konsekwencją pierwszego. Jest to jednak remedium skrajne, oparte na fałszywych - zarówno z punktu widzenia metafizycznej, jak i biblijnej wizji świata - założeniach, przyjmujące w punkcie wyjścia ontologiczną równość człowieka i przyrody.

Ksiądz Ślipko, jako charakterystyczną dla tego paradygmatu ilustrację, przywołuje sformułowaną przez Alberta Schweitzera tzw. etykę czci dla życia, której wyrazem pozostaje dewiza: „Jestem życiem, które pragnie żyć pośród życia, które pragnie żyć". Dewiza ta, zdaniem

${ }^{14}$ Na wieloznaczność terminu „humanizm” zwraca uwagę m.in. ks. bp I. Dec, analizując szereg stanowisk z zakresu metafizyki człowieka, odwołujących się do pojęcia humanizmu. Zob. tenże, Humanizmy $i$ ich roszczenia $w$ wyjaśnianiu człowieka, w: Błąd antropologiczny, red. A. Maryniarczyk, Lublin 2003, s. 49 nn. 
Schweitzera, na wzór kartezjańskiego cogito, wyraża przeżycie stanowiące jedyny dany człowiekowi bezpośrednio fakt: „,kiedy zatapiam się w myŚleniu - pisze Schweitzer - prawda ta pojawia się w mojej świadomości"15. Wydaje się jednak, że przywołany przez ks. Ślipkę przykład Schweitzera - francuskiego (choć o niemiecko brzmiącym, z racji jego pochodzenia, nazwisku) filozofa i teologa, muzyka i muzykologa, laureata pokojowej nagrody Nobla (1952), lekarza i misjonarza, który w 1913 r. wyjechał do Gabonu, gdzie za pieniądze uzyskiwane z honorariów autorskich i recitali zbudował oraz wyposażył szpital, którym kierował przez długie lata, bo aż do swej śmierci w 1965 r. - stanowi wyjątkowo pozytywny przykład myśliciela opowiadającego się za zrównaniem statusu moralnego człowieka oraz innych istot żywych ${ }^{16}$.

O tym, że zatarcie ontologicznej różnicy pomiędzy bytem ludzkim a światem zwierząt ma swoje niebezpieczne konsekwencje, świadczyć może refleksja etyczna prowadzona przez tak popularnego współcześnie autora jak Peter Singer. Występując otwarcie jako zwolennik eutanazji, Singer w sposób otwarty kwestionuje jakąkolwiek wyjątkowość człowieka w stosunku do świata przyrody. Stwierdza on: „Nikt inteligentny i pozbawiony uprzedzeń [...] nie może już wierzyć w dosłowną prawdę Księgi Rodzaju. Wraz z obaleniem hebrajskiego mitu o stworzeniu, podkopana została także wiara, że ludzie osobnym aktem stworzeni zostali przez Boga na Jego własne podobieństwo. [...] Ale jeśli nasza natura i budowa jest taka sama jak natura i budowa innych zwierząt - jeżeli jesteśmy zwierzęciem, a nie wyróżnionym bytem, stworzonym na podobieństwo Boga - jakże może to nie pomniejszyć przepaści miedzy nami a nimi? [...] Wolni od krępujących więzów religijnych, mamy nową świadomość tego, kim jesteśmy i z kim jesteśmy spokrewnieni, tego, że różnica między nami i innymi gatunkami jest niewielka oraz [...] wytyczana jest w dość przypadkowy sposób"17.

Konsekwencją antropologicznych zapatrywań Singera jest, na co zwraca uwagę ks. prof. Bortkiewicz, postulat traktowania człowieka „wyłącznie na poziomie kalkulacji kosztów związanych z eliminacją bądź

${ }^{15}$ Zob. T. Ślipko, Granice życia. Dylematy wspótczesnej bioetyki, Kraków 1994, s. 30.

${ }^{16}$ Pozytywny, biorąc pod uwagę postawę życiową Schweitzera, jego zaangażowanie na rzecz potrzebujących oraz posiadany przezeń autorytet moralny. Na poziomie metafizycznym jego „etyka czci dla życia”, co wykazuje m.in. właśnie ks. Ślipko, nie da się bowiem obronić.

${ }_{17}$ Tenże, O życiu i śmierci. Upadek etyki tradycyjnej, Warszawa 1994, s. 188-200. 
ochroną gatunków biologicznych"18. W perspektywie ludzko-zwierzęcej równości oraz jedności ludzkiego i zwierzęcego pośmiertnego losu w sytuacji ludzkiej choroby i cierpienia powraca zatem nieuchronnie pytanie postawione w tytule filmu Sydneya Polacka: „Czyż nie dobija się koni?”. O niebezpiecznych konsekwencjach, do jakich zrównanie statusu ontologicznego człowieka i zwierzęcia prowadzić może na gruncie skrajnych ruchów ekologicznych, świadczyć mogą także przywołane we wstępie przykłady ekofaszyzmu i ekoterroryzmu.

Jak stwierdziliśmy już wcześniej, podobnie jak paradygmat dominacji człowieka nad przyroda, tak również paradygmat partnerstwa opiera się na fałszywych przesłankach metafizycznych. Są one, co podkreśla m.in. - przywoływany już - ks. prof. Maryniarczyk, ściśle powiązane z monizmem na gruncie ogólnej teorii rzeczywistości ${ }^{19}$.

Historycznie rzecz ujmując, monistyczna interpretacja świata jest pierwszą, jaka pojawiła się u zarania dziejów filozofii. Zanim nastąpiło odkrycie przez Platona niematerialnego wymiaru rzeczywistości, jej pierwsi przedstawiciele próbowali wyjaśniać dającą się zaobserwować w przyrodzie zmienność zjawisk przez odwołanie się do pojęcia praelementów (żywiołów, zarodków, atomów itp.), których łączenie się i rozdzielanie miało być przyczyną procesów powstawania i ginięcia. $W$ ujęciu monistycznym wszystkie byty składają się z tych samych pracząstek, stąd też wszelkie różnice pomiędzy nimi mają jedynie charakter zjawiskowy i dotyczyć mogą co najwyżej stopnia złożoności poszczególnych bytów. Na gruncie monizmu zanika zatem podstawa jakichkolwiek jakościowych rozróżnień pomiędzy rośliną a zwierzęciem czy też światem zwierząt a światem ludzi.

Najdojrzalszym tworem tego naturalistycznego okresu greckiej filozofii był atomizm Demokryta, w myśl którego całość rzeczywistości złożona jest z niepodzielnych, elementarnych cząstek - atomów. Warto zauważyć, że współczesne odmiany materializmu i naturalizmu nie odbiegają w istotny sposób od powyższego stanowiska. Człowiek widziany z ich perspektywy, podobnie jak reszta otaczającej go przyrody, pozostaje jedynie zbiorem określonych pierwiastków, składających się na

18 Tenże, Przede wszystkim etyka, Poznań 2000, s. 67-68.

19 „W konsekwencji monistycznej interpretacji rzeczywistości - jak wyjaśnia ten autor - zanika realna podstawa zróżnicowania działania, tak w stosunku do świata osób i zwierząt, jak i roślin oraz rzeczy. Wszystko bowiem ma tę samą naturę". Tenże, Metafizyka w ekologii, s. 44. 
powszechnie znaną tablicę Mendelejewa. Stąd też, w sytuacji konfliktu interesów pojawiających się na styku człowiek-przyroda, na gruncie tych stanowisk trudno wskazać na metafizyczną rację przyznania pierwszeństwa dobru człowieka, dominująca zaś w przypadku niektórych umysłowości skłonność do irracjonalizmu pozwala uznać za słuszne hasła w rodzaju: „wszechświat istnieje po to, aby w lasach mogły rosnąć muchomory"20.

\section{PROPOZYCJA ROZWIAZZANIA - PARADYGMAT PRYMATU CZŁOWIEKA WOBEC PRZYRODY}

Przezwyciężeniem omówionych wcześniej błędnych ujęć relacji człowiek - przyroda jest - jeśli posłużyć się sformułowaniem ks. Ślipki - „paradygmat prymatu człowieka wobec przyrody”, wyrosły na gruncie realistycznej metafizyki, a zarazem pozostający w zgodności z integralnie ujętymi przesłankami biblijnymi.

\subsection{PODSTAWY METAFIZYCZNE I BIBLIJNE}

Zasadniczą przesłanką o charakterze metafizycznym, do której nawiązuje paradygmat prymatu człowieka wobec świata przyrody, jest uznanie transcendentnego charakteru osoby ludzkiej. Zarówno zewnętrzna obserwacja zachowań przedstawicieli gatunku homo sapiens, jak i wewnętrzne doświadczenie bycia człowiekiem pozwalają zaobserwować fakt spełniania przez osobę ludzką aktów, których pełna filozoficzna interpretacja okazuje się niemożliwa na gruncie samej tylko materii. W szczególności chodzi tutaj o ludzką zdolność poznania abstrakcyjnego,

${ }^{20}$ Zob. P. H. Kieniewicz, Ekologia - szansa czy zagrożenie, s. 52. Warto tutaj również wspomnieć fakt rażącej niespójności, jaką obarczona jest ideologia, wyznawana przez te spośród organizacji ekologicznych, które deklarowaną troskę o stan środowiska naturalnego łączą z hałaśliwą propagandą proaborcyjną. Na fakt ten zwrócił uwagę w swoim nauczaniu Jan Paweł II, podkreślając, że „żadnego ruchu ekologicznego nie można brać poważnie, jeżeli nie zauważa on masakrowania i unicestwiania niezliczonych dzieci, które mogłyby żyć dalej w łonie matek". Tenże, Stowo do mieszkańców Münster z 1.05.1987, w: Przemówienia i homilie Ojca Świętego Jana Pawła II, red. J. Poniewierski, Kraków 1997, s. 487. 
kontemplatywnego oraz refleksyjnego, a także możliwość dokonywania wolnych wyborów ${ }^{21}$.

Samo istnienie ludzkiego języka świadczyć może wystarczająco o wyjątkowości człowieka, który w komunikacji z innymi ludźmi nie ogranicza się do wydawania nieartykułowanych dźwięków, ale nazywa rzeczywistość (nazwa jest materialnym znakiem istniejącego w ludzkim intelekcie pojęcia, utworzonego wcześniej $\mathrm{w}$ procesie abstrakcji - oderwania cech wspólnych danej klasie przedmiotów od ich jednostkowo-materialnego podłoża). Wyjątkowość tę potwierdzają także pozostałe rodzaje poznania, bezużyteczne $z$ punktu widzenia tworzenia narzędzi oraz przetrwania $\mathrm{w}$ środowisku naturalnym, a jednak silnie angażujące człowieka, który zdolny jest kontemplować piękno, a także reflektować świadomie swój los (specyficznie „ludzkim” wynalazkiem są galerie i muzea, a także cmentarze rozumiane jako miejsca pamięci o zmarłych i zadumy nad własnym życiem). O wyjątkowości człowieka świadczy także fakt, że - w przeciwieństwie do działających na mocy instynktu zwierząt - jest on w poszczególnych sytuacjach zdolny przezwyciężyć instynkt, manifestując w ten sposób swoją wolność.

Jest rzeczą powszechnie znaną, że w codziennym obcowaniu ze zwierzętami niektórzy skłonni bywają przypisywać swoim ulubieńcom takie „ludzkie” aktywności, jak myślenie, rozumienie, „pamiętanie” itp. Powyższa skłonność do antropomorfizacji zwierzęcych zachowań wyrasta zazwyczaj na gruncie emocjonalnego przywiązania człowieka do żywego stworzenia, będącego towarzyszem rozrywki, pracy, niekiedy także antidotum na ludzką samotność. Nie zmienia to faktu, że wszelkie przejawy rzekomej rozumności zwierząt dają się z powodzeniem wyjaśnić na gruncie właściwego im psychizmu (dość uświadomić sobie, że jako ludzie również posiadamy, przyporządkowaną naszej sferze cielesnej, pamięć zmysłową - kojarzymy zapachy, dźwięki - a także pamięć motoryczną, szczególnie ważną w przypadku nauki gry na instrumentach muzycznych, opanowywaniu sztuk walki, obsługi niektórych urządzeń itp.).

Już w średniowieczu podkreślano, że przy całej obserwowanej „zmyślności” zachowań zwierząt są one zdeterminowane ad unum genus operabilium - „do określonego zespołu działan”", charakterystycznych dla danego gatunku. W fakcie tym - jak zauważa ks. Ślipko - tkwi przyczyna bezbronności zwierząt wobec człowieka, który posługując się rozumem,

${ }^{21}$ Problematykę tę omawia szerzej m.in. o. Krąpiec. Zob. tenże, Filozofia w teologii, Lublin 1999, s. 53 nn. 
potrafi odczytać prawidłowość zwierzęcych zachowań i wiedzę tę wykorzystywać (np. stosując odpowiednie techniki łowieckie)22.

Drugą, obok uznania transcendentnego charakteru osoby ludzkiej, przesłanką, do której nawiązuje paradygmat prymatu człowieka wobec przyrody, jest uznanie istnienia obiektywnego ładu moralnego, którego człowiek nie tworzy, ale który zastaje i odczytuje. Na płaszczyźnie metafizyki uznanie tego ładu wyrażać się będzie w formie postulatu afirmacji każdego bytu stosownie do poziomu jego bytowania. Zło - widziane $\mathrm{w}$ tej perspektywie - będzie wynikiem rozminięcia się ludzkich działań $\mathrm{z}$ naturą ich adresata. $\mathrm{W}$ tym kontekście za całkowicie zasadne uznać trzeba hasło lansowane przez niektóre środowiska ekologiczne, w myśl którego „zwierzę nie jest rzeczą”. Ludzki intelekt odczytujący prawdę bytu $\mathrm{w}$ sposób oczywisty rozpoznawać będzie jako niezgodne $\mathrm{z}$ naturą bytu-zwierzęcia (a zatem złe), a więc istoty, która czuje i cierpi, tak jakby była ona nieożywionym przedmiotem. Podobnie jednak sprzeciwiać się będzie stawianiu w sytuacjach konfliktowych dobra zwierzęcia na równi z dobrem osoby ludzkiej.

Paradygmat prymatu człowieka wobec przyrody ma również swoje podstawy biblijne. Pismo Święte z jednej strony podkreśla fakt wyjątkowości człowieka oraz jego uprzywilejowanej pozycji w stosunku do świata przyrody, z drugiej natomiast akcentuje prawdę, że zarówno on sam, jak i reszta stworzeń należą do Boga, który jest Panem świata.

Opis stworzenia zawarty w Księdze Rodzaju notuje niezmiernie ważną z punktu widzenia antropologii prawdę, w myśl której człowiek stworzony zostaje "na obraz Boży"23. To podobieństwo do Boga, będące zarazem źródłem transcendencji osoby ludzkiej w stosunku do świata przyrody, wiąże się - jak wyjaśnia Katechizm Kościoła Katolickiego - z faktem posiadania nieśmiertelnej duszy wraz z jej władzami: rozumem i wolą ${ }^{24}$. Psalmista głosząc pochwałę Stwórcy i godności człowieka, stawia swe słynne pytanie: „Czym jest człowiek, że o nim pamiętasz i czymże syn człowieczy, że się nim zajmujesz?", na które zaraz też odpowiada:

${ }^{22}$ Zob. Granice życia, s. 58-59. Podobnie o. Krąpiec zwraca uwagę na istotną różnicę pomiędzy "inteligencją", przypisywaną niekiedy zwierzętom, wyrażającą się w ich zdolności adaptacji do warunków środowiska naturalnego, a inteligencją człowieka, który - rozumiejąco poznając i opanowując przyrodę - potrafi tworzyć sobie także sztuczne (kulturowe) warunki, potrzebne mu do istnienia i rozwoju. Zob. tenże, Ja - człowiek, Lublin 1991, s. 60.

${ }^{23} \mathrm{Rdz} 1,27$.

${ }^{24}$ Zob. tamże, 1705. 
„Uczyniłeś go niewiele mniejszym od aniołów"25. Także sam Chrystus Pan podkreśla fakt górowania człowieka nad światem zwierzęcym, dodając słuchającym Go otuchy słowami: „Nie bójcie się: jesteście ważniejsi niż wiele wróbli"26, a dla uzdrowienia opętanego człowieka nie waha się posłać na zagładę dwutysięczną trzodę świnin ${ }^{27}$.

Obok powyższych tekstów znajdujemy jednak również inne, wskazujące na fakt, że świat jest światem Pańskim, człowieka zaś obowiązuje zachowanie ustanowionego przez Boga porządku moralnego. Wspomnieć tu należy w pierwszym rzędzie, cytowany już wcześniej, fragment z Księgi Mądrości, przypominający, że władanie człowieka nad światem ma się realizować „W świętości i sprawiedliwości” oraz „W prawości serca”28. W Księdze Psalmów czytamy, że „Pana jest ziemia i co ją napełnia, krąg ziemi i jego mieszkańcy”29, a także: „Twoje jest niebo i Twoja jest ziemia, Tyś ugruntował krąg ziemski z tym, co go napełnia"30. Chwałę Stwórcy, który jako władca ziemi obdarza ją nieskończonym pięknem i bogactwem, głosi również hymn trzech młodzieńców z Księgi Daniela ${ }^{31}$. Słowa napomnienia, zaznaczające fakt panowania Boga nad światem, znajdujemy też w Księdze Kapłańskiej: „Nie wolno sprzedawać ziemi na zawsze, bo ziemia należy do mnie, a wy jesteście u mnie przybyszami i osadnikami"32.

Warto też podkreślić, że nieuporządkowany stosunek człowieka do świata przyrody jest $\mathrm{w}$ perspektywie biblijnej ukazany jako następstwo nieposłuszeństwa i grzechu, stąd skarga Boga na nieprawe użytkowanie ziemi:

\footnotetext{
"Zaprawdę wwiodłem was do ziemi - ogrodu, na pożywanie jej owoców i dóbr, aleście wszedłszy, skalali mą ziemię, i włość moją zamienili w ohydę"
}

${ }^{25}$ Ps 8,5-6. W tekście hebrajskim pojawia się nawet stwierdzenie: „niewiele mniejszym od Boga", co oddają również niektóre przekłady.

26 Łk 12,7 .

27 Zob. Mk 5,1-13.

${ }^{28} \operatorname{Mdr} 9,3$.

${ }^{29}$ Ps $24,1$.

${ }^{30}$ Ps 89,12 .

${ }^{31}$ Dn 3,52-90.

$32 \mathrm{Kpł} \mathrm{25,23.}$

${ }_{33}$ Jr 2,7. 


\subsection{POSTULATY PRAKTYCZNE}

Na gruncie przedstawionych powyżej stwierdzeń, dotyczących natury człowieka i jego relacji do otaczającego go świata, można sformułować szereg praktycznych postulatów, realizacja których może być zakwalifikowana jako roztropna troska o środowisko naturalne. Ze względu na fakt, że w tytule naszego wykładu owa "roztropna troska” przeciwstawiona została zjawisku ekoterroryzmu (które - jak wcześniej wspomnieliśmy - w sposób zasadniczy pojawiło się w kontekście relacji człowieka do świata zwierzęcego), formułując wspomniane postulaty, przywołać pragniemy w tym miejscu tekst Katechizmu Kościoła Katolickiego, w zwięzłej formie ujmujący zasadnicze kwestie, dotyczące tej relacji:

„Bóg powierzył zwierzęta zarządzaniu człowieka, którego stworzył na swój obraz. Jest wiec uprawnione wykorzystywanie zwierząt jako pokarmu i do wytwarzania odzieży. Można je oswajać, by towarzyszyły człowiekowi w jego pracach i rozrywkach. Doświadczenia medyczne na zwierzętach są praktykami moralnie dopuszczalnymi, byle tylko mieściły się $\mathrm{w}$ rozsądnych granicach i przyczyniały się do leczenia i ratowania życia ludzkiego.

Sprzeczne z godnością ludzką jest niepotrzebne zadawanie cierpień zwierzętom lub ich zabijanie. Równie niegodziwe jest wydawanie na nie pieniędzy, które mogłyby raczej ulżyć ludzkiej biedzie. Można kochać zwierzęta, nie powinny one jednak być przedmiotem uczuć należnym jedynie osobom" ${ }^{\prime 3}$.

W świetle powyższego tekstu, jak i przeprowadzonych wcześniej rozważań możemy sformułować, w formie końcowych wniosków, następujące postulaty będące wyrazem roztropnej troski o środowisko naturalne:

1. Zarówno realistyczna metafizyka, jak i światło Bożego objawienia odkrywa przed nami świat stworzeń różniących się pomiędzy sobą w aspekcie swojej bytowej doskonałości. Bytem najdoskonalszym - pełnią Bytu, Stwórcą i Panem świata, a także jego ostatecznym celem, pozostaje jedynie sam Bóg. Człowiek natomiast, stworzony na jego obraz i podobieństwo, przewyższa swoją godnością świat otaczającej go przyrody, która jako podporządkowana jego dobru ma służyć realizacji 
celów osoby ludzkiej. Zgodne z naturą świata materialnego (także zwierzęcego) jest zatem traktowanie przez osobę ludzką tego świata w sposób instrumentalny.

2. Poszanowanie ustanowionego przez Stwórcę ładu oraz własnej godności osobowej każe jednak eksploatacji środowiska naturalnego przez człowieka wyznaczyć pewne roztropne granice, których podstawą jest solidarna troska o los innych ludzi, żyjących współcześnie oraz w przyszłych pokoleniach ${ }^{35}$. Świadomość obciążenia gatunku ludzkiego skutkami grzechu pierworodnego i związana z nim pokusa konsumizmu każą sformułować postulat swoistej „ascezy ekologicznej” tak, by - według słów Jana Pawła II - „powstrzymać nieumiarkowaną konsumpcję dóbr doczesnych i unikać mnożenia sztucznych potrzeb"36.

3. Jest rzeczą oczywistą, że w otaczającym nas świecie poszczególne dobra wchodzą ze sobą we wzajemne konflikty. Nie byłoby np. rzeczą możliwą - jak zauważa ks. Ślipko - utrzymanie stanu środowiska naturalnego z czasów średniowiecza, bez zgody na konsekwencje tego faktu, w postaci pozostania na ówczesnym, prymitywnym poziomie rozwoju cywilizacyjno-technicznego. Przy podejmowaniu konkretnych decyzji powstaje zatem konieczność rozważenia proporcji zachodzącej pomiędzy oczekiwanym dobrem - w postaci korzyści, wypływających dla ludzkości z osiąganego postępu cywilizacyjnego - a kosztami, jakie wypada $\mathrm{w}$ związku z nim ponosić, w postaci skażenia środowiska oraz jego dalszych konsekwencji dla ludzkiego zdrowia, egzystencji przyszłych pokoleń itp.

4. Źródłem poznania norm dotyczących relacji człowiek - świat zwierzęcy jest ludzka rozumna natura (znamienne jest, że

${ }^{35}$ Jan Paweł II zwraca uwagę na to, że narody ekonomicznie słabe, pozostając pod presją państw bogatych, zmuszane są za cenę rabunkowej gospodarki powodującej dewastację środowiska naturalnego do zawierania niekorzystnych dla siebie umów międzynarodowych. Papież przypomina w tym kontekście, że zimny rachunek ekonomiczny musi znaleźć swoje granice. Zob. tenże, Orędzie na Światowy Dzień Pokoju 1993 - Jeśli pragniesz pokoju, wyjdź naprzeciw ubogim.

${ }^{36}$ Tamże. Papież stwierdza też, że „umiarkowanie i prostota winny stać się kryterium naszego codziennego życia”, wskazując tym samym na konieczność przezwyciężenia przerostów cywilizacji nastawionej na konsumpcję, naznaczonej marnotrawstwem, produkującej nadmiar „odpadków” i „rzeczy do wyrzucenia”. Zob. T. Zadykowicz, Potrzeba "ascezy" ekologicznej, w: Ekologia. Przestanie moralne Kościota, s. 156-157. 
Katechizm wymieniając skrajne ludzkie postawy w stosunku do zwierząt, w postaci zadawania im zbędnych cierpień bądź też przeznaczania na nie nadmiernych środków, które mogłyby ulżyć ludzkiej biedzie, stwierdza, że zachowania takie są „sprzeczne z godnością ludzką").

5. Rozum ludzki odczytuje jako dopuszczalne i uzasadnione wykorzystywanie zwierząt $\mathrm{w}$ celu pozyskiwania pokarmu oraz odzieży, jak również wykorzystywanie ich w rozmaitych pracach oraz rozrywkach, a także przeprowadzanie na nich doświadczeń naukowych, zmierzających $\mathrm{w}$ dalszej perspektywie do ratowania zdrowia i życia ludzkiego ${ }^{37}$. Zadawanie zwierzętom cierpienia ma $\mathrm{w}$ perspektywie etycznej charakter zła fizycznego, które - jako takie - może zostać dopuszczone ze względu na odpowiednio ważne przyczyny ${ }^{38}$.

6. Równocześnie jednak ten sam ludzki rozum pozwala ocenić jako sprzeczne z godnością ludzką, a tym samym moralnie niedopuszczalne zadawanie zwierzętom nieuzasadnionych cierpień. Wydaje się, że wymienić można w tym kontekście zarówno przypadki bezmyślnego znęcania się nad zwierzętami, jak i niektóre formy krwawych rozrywek z ich wykorzystaniem (jak np. korrida). W przeprowadzanych na zwierzętach doświadczeniach przywołać należy w tym kontekście postulat zabraniający przeprowadzania na organizmach wyższej zorganizowanych (a co za tym idzie posiadających większą zdolność odczuwania bólu) doświadczeń, których przeprowadzenie jest możliwe na organizmach niższych lub też z zastosowaniem znieczulenia.

7. Jako niezgodne z porządkiem rozumu należy ocenić również sytuacje, w których - jak zauważa Katechizm - zwierzęta stają się przedmiotem uczuć należnych jedynie osobom lub też gdy przeznacza się na nie nieproporcjonalnie poważne środki materialne w sytuacji, w której środki te mogłyby ulżyć ludzkiej biedzie. Stan rzeczy, w którym dopuszczone zostaje ludzkie

${ }^{37}$ Chodzi tutaj, rzecz jasna, o ludzki rozum jako taki, pojęty gatunkowo, wolny od obciążeń i ułomności, jakimi dotknięte może być poznanie jednostki, niekiedy zaś również całych grup społecznych, które mogą pozostawać w błędzie. Św. Tomasz z Akwinu wyjaśnia to zagadnienie w swej Sumie Teologicznej. Zob. tamże, I-II, 94, 4.

${ }^{38}$ W szczególności chodzi tutaj o problem wiwisekcji, a więc doświadczeń medycznych przeprowadzanych na żywych organizmach zwierzęcych. 
cierpienie $\mathrm{w}$ imię pomocy niesionej zwierzęciu (zwierzętom), stanowi pogwałcenie porządku natury, który na poziomie metafizyki odczytuje przyrodzony rozum, w perspektywie zaś Objawienia nadprzyrodzonego poznaje rozum oświecony wiarą.

\section{PODSUMOWANIE}

Kwestie dotyczące ochrony środowiska naturalnego należą współcześnie do żywo dyskutowanych. Świat przyrody przez całe wieki stanowił dla człowieka środowisko, z którym musiał się on zmagać w trudnej walce o przetrwanie. Dynamiczny postęp techniczny, jakiego świadkami jesteśmy w ostatnich stuleciach, przyczynił się do powstania nowej sytuacji, w której to nie tylko przyroda zagrażać może człowiekowi, ale także on wpływać może destrukcyjnie na stan środowiska naturalnego.

Konieczność troski o środowisko naturalne wydaje się $\mathrm{w}$ tym kontekście czymś oczywistym i niepodlegającym dyskusji. Kontrowersje pojawiają się natomiast wraz z próbami ustalenia, w jakich postawach oraz działaniach troska ta miałaby się konkretnie wyrażać. Praktyka życiowa pokazuje, że wypada stawać niejednokrotnie wobec sytuacji, w których w konflikt wchodzą ze sobą poszczególne dobra: budowa bezpiecznej drogi oznacza zniszczenie terenów zielonych, postęp medycyny, który w dalszej perspektywie przyczynić się ma do ratowania zdrowia i życia ludzkiego, zakłada konieczność prowadzenia bolesnych niekiedy doświadczeń na zwierzętach, dążenie do podniesienia życiowego komfortu zakłada rozwój przemysłu, który negatywnie wpływa na stan środowiska naturalnego itp.

Obok przejawów roztropnej troski o to środowisko mamy współcześnie do czynienia z szeregiem postaw oraz inicjatyw skrajnych, których przejawem jest m.in. zjawisko tzw. ekoterroryzmu. Ekoterroryści, inspirowani monistyczną wizją rzeczywistości, w której zatarciu ulegają istotne różnice pomiędzy człowiekiem a otaczającym go światem przyrody, gotowi są podejmować działania godzące w ludzkie życie i zdrowie, w imię obrony rzekomych "praw zwierząt”.

Aktualnym zadaniem pozostaje zatem poszukiwanie oraz ukazywanie światopoglądowych podstaw, na których oprzeć mogła by się postawa odpowiedzialnej i roztropnej troski o środowisko naturalne, wyrażająca się $\mathrm{w}$ podejmowaniu trafnych decyzji we wspomnianych wyżej sytuacjach konfliktu dóbr. Zarówno realistyczna metafizyka, jak 
i pogłębiona refleksja nad tekstami biblijnymi pozwalają odkryć prawdę o człowieku i jego relacji do otaczającego go świata, na gruncie której cel taki można osiągnąć.

Abstract. Eco-terrorism and sagacious care for natural environment - its metaphysical and biblical aspects. Problems relating to protection of natural environment are lively discussed nowadays. The world of nature used to be for a human being an environment, in which he had to fight for survival. The dynamic progress of technology, which we experienced in the last centuries, contributed to existence of a new situation, in which it is not only nature that may pose a threat to a human being, but a human being may affect natural environment in a more destructive manner as well.

The need to care for natural environment seems to be something obvious and unquestionable in this context. However, controversies arise at attempt to determine attitudes and activities, which should embody the care. The practice shows that one has to face numerous situations, in which particular types of well-being conflict with one another, namely construction of a safe road involves destruction of greenery, progress in medicine, which, in a longer perspective, is to contribute to saving of human life and health, assumes the need to perform painful experiments on animals and striving to improve human comfort assumes development of industry, which affects natural environment etc.

Apart from manifestations of sound care about the environment, nowadays we also deal with a series of extreme attitudes and initiatives, which are manifested, among other in, a phenomenon referred to as eco-terrorism. Eco-terrorists, who are inspired by a monistic vision of reality, in which significant differences between a human being and his natural environment, are erased, are ready to undertake activities, which pose a threat to human life and health for the sake of alleged protection of "animals' rights".

Thus, a current task is still to search for and show world view attitudes, which could constitute a basis for reasonable and sound care for the natural environment expressed in making right decisions as regards the above-mentioned cases of conflict between well-beings. Both realistic metaphysics and deep reflection on biblical texts will make it possible for one to discover the truth about a human-being and his relations with his environment, which will constitute a basis for achievement of this aim. 